\title{
Physicians' Behavior in Referring National Health Insurance Patients to Hospital
}

\author{
Perilaku Dokter dalam Merujuk Pasien Jaminan Kesehatan Nasional Ke Rumah \\ Sakit
}

\author{
Natalia $^{1}$, Haerawati Idris ${ }^{1}$ \\ Correspondence: Haerawati Idris \\ E-mail: haera@fkm.unsri.ac.id
}

${ }^{1}$ Faculty of Public Health, Sriwijaya University, Raya Palembang-Unsri KM 32 Indralaya Street, Ogan Ilir, South Sumatera

\begin{abstract}
Physicians' decision to refer patients in primary health care is vital in supporting the referral system. The increase of referral cases impacted the claims cost and hospital workload. This study aimed to analyze the physicians' behavior in referring National Health Insurance (NHI) patients to hospitals. This study employed a qualitative method; 18 informants were selected using purposive sampling and analyzed using content analysis. The data were validated by triangulating method, source, and data. Physicians referred patients when the cases could not be handled; there were indications of severe disease and required further examination. The obstacles in the referral system were pressure from NHI patients that wanted to be referred and diagnosed differently from ICD 10. In referring NHI patients, physicians had followed referral procedures and criteria. High referrals were caused by patients being forced to be referred, coming with complaints of severe disease, having examined in a hospital, and some cases should not be referred to but still referred by entering a similar diagnosis into the ICD 10. It is expected that public health centers will educate $\mathrm{NHI}$ patients related to tiered referral procedures in health services.

Keywords: referral, physician, national health insurance
\end{abstract}

\begin{abstract}
Abstrak
Keputusan dokter Puskesmas untuk merujuk pasien sangatlah penting dalam mendukung sistem rujukan era Jaminan Kesehatan Nasional (JKN). Tingginya rujukan menyebabkan peningkatan biaya klaim dan beban kerja rumah sakit. Penelitian ini bertujuan untuk mengetahui perilaku dokter dalam merujuk pasien JKN ke rumah sakit. Penelitian ini menggunakan desain studi kualitatif; 18 informan dipilih dengan metode purposive sampling dan dianalisis menggunakan analisis isi. Validasi data dilakukan dengan triangulasi metode, sumber dan data. Hasil penelitian menunjukkan dokter merujuk pasien ketika kasus tersebut tidak dapat ditangani; ada indikasi penyakit serius dan perlu pemeriksaan lebih lanjut. Hambatan dalam sistem rujukan adalah tekanan dari pasien JKN untuk dirujuk dan didiagnosis berbeda dengan ICD 10. Dalam merujuk pasien JKN, dokter telah bertindak sesuai prosedur dan kriteria rujukan. Tingkat rujukan yang tinggi disebabkan oleh pasien yang terpaksa dirujuk, datang dengan keluhan sakit parah, datang setelah memeriksakan diri ke rumah sakit, dan beberapa kasus tidak boleh dirujuk tetapi tetap dirujuk dengan memasukkan diagnosis serupa ke dalam ICD 10. Oleh karena itu, Puskesmas diharapkan dapat mendidik peserta JKN terkait prosedur rujukan berjenjang dalam pelayanan kesehatan.
\end{abstract}

Kata kunci: rujukan, dokter, jaminan kesehatan nasional

\section{Introduction}

General Practitioner (GP) referral level is a crucial determinant in secondary health services utilization (Førde, Breidablik, \& Øgar, 2011). In many countries, referrals from Primary Care
Providers (PCP) to specialists are essential for patients to access health services. However, the referral process encounters challenges and increasing demand, resulting in excessive waiting 
times for many people (Ringberg, Fleten, Deraas, Hasvold, \& Førde, 2013). Many countries and the World Health Organization adopted strategies to improve primary care services as a response to the increase of health quality and maintenance costs (Coyle, Hanley, \& Sheerin, 2011).

A study conducted by Thorsen (2017) reported that doctors experienced pressure from patients to be referred, especially younger doctors, as a reason for referral. Moreover, young male doctors experienced more workload and pressure from patients when referring to hospitals. A study conducted in Norwegia stated that female doctors referred significantly more frequently than male doctors and salaried doctors referred more frequently than private doctors (Ringberg et al., 2013).

The referral system should follow existing regulations; otherwise, it will have adverse consequences. These negative impacts include increasing claims cost and hospital staff workload due to the duties and responsibilities of Public Health Center (PHC) officers. These problems can affect the financial aspect and the quality of health services. The level of referrals from First Level Health Facilities (FLHF) to Advanced Health Facilities (AHF) in Indonesia is relatively high. Referral from first-level health facilities should only be done if it meets one of the "TACC" criteria. Referrals can only be made by physicians and dentists who provide services. In contrast, midwives and other health workers can only make referrals to physicians and dentists at first-level health facilities. Physicians' decisions to refer patients have a significant consequence because physicians are health workers who examine and determine the patients' diagnoses.

The data were obtained from BPJS Kesehatan KCU Palembang. It showed that the referral rate of JKN patients from first-level health facilities to hospitals in 2017 was $17.2 \%$. The referral rate from public health centers to the hospital was also relatively high. The highest referral rate occurred at the Dempo Health Center. Dempo Health Center is one of 42 Puskesmas located in Palembang City. The referral percentage from Dempo Health Center to hospitals from September to November 2017 reached 97.2\%. The referral rate exceeded the optimal value that BPJS Kesehatan determined, which is $15 \%$ for all cases. The high number of referrals can affect the referred hospital.

Health workers such as FLHF physicians must make clinical diagnoses and determine diseases with at least 144 diagnoses in clinical practice guidelines according to the 4A competency level based on Indonesia Medical Doctor Competency Standard (SKDI). The objective of this study was to analyze physicians' behavior in public health centers (PHC) in referring National Health Insurance (NHI) patients to hospitals.

\section{Method}

The study employed a qualitative method based on theory of the Health Belief Model. The Health Belief Model contains several main concepts that predict why people will take action to prevent, filter, or control disease. The Health Belief Model consists of vulnerability, seriousness, benefits, barriers to behavior, instructions for action, and self-efficacy. Perceived vulnerability is personal feelings that are detrimental to a condition. Perceived severity is a person's belief about the consequences of a health problem that will worsen, thus encouraging people to seek disease prevention and treatment. Perceived benefits are positive outcomes that a person believes in because of an action. Perceived barriers are personal evaluations of obstacles to behavior change. Self-efficacy is belief in one's own ability to do something.

This study interviewed 18 informants consisting of physicians at the Dempo PHC, referral officers, referred NHI patients during the study, and one person in charge of the primary 
benefits guarantor in Palembang. Informants were selected using a purposive sampling method, considering they would provide a lot of experience and information needed and be involved in the referral implementation. Palembang's Dempo PHC was chosen as the location of this study based on the high percentage of referrals.

The data were collected using document analysis, in-depth interviews, and observations. Document analysis was conducted by analyzing referrals-related data, namely visits and referrals, the availability of medical devices, the reports on the use of medicine and receipt, and the number of capitation payments. In-depth interviews were conducted face-to-face with the informants using interview guidelines, recording devices, and taking notes to record important information during interviews. The questions in the interview guidelines were arranged based on the HBM theory, and the designed definition of terms was then asked directly to the informants. The observation was carried out by observing the referral implementation using an observation sheet based on referral procedures and criteria from the Minister of Health Regulation (MHR) No. 1 of 2012 and No. 5 of 2014. The data were validated by triangulating method, source, and data. Furthermore, the data were processed by transcribing, sorting, coding, and interpreting. The data were analyzed using content analysis, which was concluded objectively by finding the informants' statement characteristics.

\section{Findings}

Physicians referred patients when the cases could not be handled at the PHC; there were indications to be referred and required further examination. After the physician examined and determined the patient's diagnosis, a referral was conducted. The referral procedure observation showed that the physician performed first aid if necessary, stabilized the emergency patient's condition, and communicated with the referral recipient by telephone. Referral letters were made through the P-care application that included the patient's identity, the examination results, diagnosis, the purpose of the referral, and the name and signature of the service provider. Referrals were conducted vertically to a higher level, namely type $\mathrm{C}$ hospitals, considering that patients needed a specialist or subspecialist health services. The referral criterion of time was implemented in patients with chronic diseases such as heart disease, diabetes mellitus, and hypertension. Age was considered for elderly patients. Some patients were found with disease symptoms and complications that aggravated patients' condition, such as lumps and lung disease symptoms.

Based on the results of in-depth interviews with physicians and referral officers, there were some cases in which some patients requested referral, coerced, and even debated the physicians and referral officers. The physician or referral officers would first explain the patient's condition in such cases.

"Sometimes the patients insisted because, according to them, they wanted to be in a good hospital with better physicians. Especially, the patients here are mostly Chinese" (IK 2)

If the patient insisted, then the physician would make a referral letter by providing records at the patient's request, and the patient was required to pay as a public patient.

"But if the patients got angry, sometimes it led to a quarrel because they wanted to be referred, we eventually gave them the referral at their request" (IK 6)

"Asked them to pay for themselves if they insisted so that they became public patients" (IK 3) 
In-depth interviews with patients showed that referral rates were affected by patients' willingness to be referred and hospital physicians' advice. Of the ten patients interviewed, four patients were referred because of their own volition, five patients because of hospital physician's advice, and the PHC physician referred one patient. It was also known that patients' symptoms had been examined in the hospital before coming to the PHC. They felt that their disease were severe because they did not recover after several treatments at the PHC, and some patients had never been to the PHC but only asked for referrals. In such cases, the physician decided to refer the patients to avoid a lengthy debate after giving them explanations, but the patients insisted on being referred.

The number of referrals in Dempo PHC based on the referral data for 43 days in January-April 2017 was 825 referrals, with an average referral per day ranging from 19-20 patients. The results were not significantly different from in-depth interviews, which found that the referrals ranged from 10-38 patients per day depending on the condition and number of patient visits. In three departments, namely pediatrics, dentistry, and ob-gyn or $\mathrm{MCH} /$ family planning, there were only one to two referrals per day.

"Sometimes there were some referrals in a day. It was not necessarily any referral in a day, and there was at least one referral or none at all" (IK4) (Pediatrics department)

Physicians referred NHI patients by considering the patients' condition and necessities for further examination. Physicians believed that if the case required further examination but were inadvertently handled at the PHC, it would be detrimental for the patient. The referral hospital was chosen to consider the distance between the patient's house and the hospital.
The vulnerability was seen from the availability of medicines and medical devices. The results of the study showed that most physicians did not feel vulnerable to refer the patients based on the availability of medicines because the referred cases required particular medicine. However, at pediatrics and ob-gyn departments, the physician said the medicine was not comprehensive. There were still medicines that were not available and limited in stock; therefore, the physician prescribed medication outside the hospital. The data on the use of medicines and receipt reports showed that medicine inventory was recorded every month. However, the supply of medicines was on request before being distributed so that the available medicines were estimated of previous usage.

"There was no ob-gyn medicine in the PHC. The stock was limited. The required medicine was at least calcium, folic acid, and other specific hormone medicines that did not have to be prescribed" (Ob-gyn department)

Based on the data of medical devices availability, according to HMR of the Republic of Indonesia No. 75 of 2014, it was known that there were 13 medical devices in $\mathrm{MCH}$, family planning and immunization departments. The PHC required 49 medical devices, which were unavailable. Thirty-three medical devices were needed in the general examination rooms, but only 27 medical devices were available. Eightythree medical devices were required in the emergency department, but there were only 51 devices available. The dentistry department required 72 medical devices, but only 25 were available. These results indicated that medical devices requirements were not met. However, based on the interviews with physicians and referral officers, only two physicians felt that the lack of medical devices caused the patients' referrals. In contrast, the four other physicians and officers believed that the medical devices 
were sufficient to provide medical services in the PHC.

"We feel that we had adequate equipment for cases that were intended to be handled in the PHC. " (IK 1)

In-depth interviews with physicians showed that referring NHI patients could negatively impact services if the cases were non-specialist, such as reduced services, reprimanded, and reduced capitation payments. On the other hand, physicians felt that there was no impact in general patient referral.

"The PHC got angry with the health insurance providers. Sometimes, I did not experience any impact, but sometimes it was mostly reduced services..." (IK 4)

"General patients did not have a significant impact. If we believed that the cases could not be handled, we referred them. However, the NHI patients had an impact on our capitation payments..." (IK 6)

On the other hand, Commitment-Based Capitation $(\mathrm{KBK})$ data analysis showed that the ratio of non-specialist referrals in April-June 2018 was $2.72 \%$, below the maximum service commitment fulfillment target of $5 \%$. Unacceptable ratios occurred in communication contacts and Prolanis; therefore, the PHC only obtained the capitation of $92.5 \%$. The observations showed that the Palembang Health Centers did not reprimand or evaluate the received capitation. They directly provided capitation funds that had been cut based on the assessment criteria. PHC only accepted capitation and did not reciprocate the capitation amount received. Moreover, PHC did not evaluate which components had an unacceptable ratio, so they did not know the components that made their capitation payments were not fully paid. The Puskesmas Quality Improvement (PMP) director explained that Dempo PHC achievement was indeed low because the Prolanis component had not been running. At the same time, the nonspecialist referral was less than $1 \%$.

"Dempo PHC was correct (seeing data on a computer); the non-specialist outpatient referral ratio was not high. It was zero in our application and might be zero point something. However, many referrals were not non-specialist, and the Prolanis was not performing. It was $92.5 \%$, and it was lower than the KBK achievement." (IB 2)

Perceived advantage is related to benefits felt when referring NHI patients. Some physicians feel calm because the patient can be treated in hospitals and happy because the patient's disease can be addressed as indicated. Patients are getting the optimal treatment, cured, and become healthy. The referral officers said that the possibility of reducing physicians' workload was one of the advantages felt. However, most physicians said there were no perceived advantages in referring NHI patients to hospitals.

"The advantage of referring patients was that their disease could be addressed according to the indication, and treated following their needs. " (IK 2)

"The advantage was that the patients could recover after they were referred so that we get the pleasure of doing something right" (IK 5)

Some physicians felt stressed to refer NHI patients. The patient asked the physician to be referred, even though it was not allowed. It caused the physician to be forced to refer the patient. The patient's coercion finally made the physician find a new diagnosis that allowed the patient to be referred to the hospital.

"How could they ask for referrals even though we can perform the examination here. 
We had explained, but they did not want to hear; finally, we were forced to look for a diagnosis that could be used to refer the patient." (IK 2)

Physicians also experienced technical obstacles in referring NHI patients. These obstacles were power outages, poor internet connection, and the patients' diagnoses were different from ICD 10. The patients also interfered with the referral process, including the lack of understanding of the referral mechanisms and incomplete requirements. The observation also found that poor internet connection caused the online data input process to run slowly and some patients were forced to be referred. Some patients had been made referrals but wanted to be moved to another hospital, did not bring their family certificate and a valid referral letter, and wanted to be referred directly to their hometown.

Physicians referred patients because they understood the diagnosis that could be referred based on referral criteria, clear referral indicators, and referral requirements. Physicians were convinced to refer patients when they did not know the diagnosis of the disease and that the diagnosis was not categorized in 144 diseases that must be handled in First Level Health Facilities (FLHF).

"We already knew the cases and the limitation of a certain diagnosis. We already knew the limitation of the cases that should be referred." (IK 1)

The interviews results showed the often referred diagnoses were chronic diseases that required further examination, such as hypertensive heart disease (HHD), diabetes, heart disease, hypertension, stroke, schizophrenia, child tuberculosis, high-risk pregnancy, child anemia, drowning teeth, and hypertension in pregnancy. Regarding the diagnoses of chronic diseases that were often referred, the PMP director recommended that those diagnoses to be included in the referral program.

"If the patients had Diabetes Mellitus (DM), hypertension, heart and lung diseases, and asthma, they could be included in the reconciliation program." (IB 2)

The document analysis of referral data showed that the frequently referred diagnoses were HHD without heart failure, schizophrenia, DM type 2 with renal complication, allergic contact due to metals dermatitis, low back pain, chest pain, stroke that was not specified as hemorrhage or hemorrhage infarction, and senile incipient cataract. The frequently referred cases in the dentistry department were impacted teeth, accidental loss of teeth, extraction, and local periodontal disease. In the $\mathrm{MCH}$ or FP department that a specialist had handled, the supervision of high-risk pregnancies caused by the lack of medicine for the department was the frequently referred diagnosis.

The physician decision to refer NHI patients was reflected in how physicians responded to some cases related to referrals. The physician would examine and verify the patient's condition before making a referral letter. They would refer the patient if the chosen hospital were type $\mathrm{C}$ and collaborate with the PHC. They would also provide a referral letter if the patient's condition was emergency and required a referral letter from the hospital ER physician. However, nonemergency patients should come to the PHC first.

"Maybe in an emergency case. However, if it was not an emergency, they could not be given a referral and then the patient must come, right? If the patient did not come, they could not be referred" (IK 4)

The result of observations indicated that physicians and referral officers had briefed patients who were looked to be referred for their medical conditions. They explained the selected 
hospital and whether their disease could be treated at the hospital. When conducting observations, interviews were also conducted with patients to obtain additional information that supported the observation results. The referred patients were patients who did not recover after being treated in the PHC. They were required to bring a referral letter from the hospital physician during an emergency and came when it was not an emergency.

\section{Dicussion}

According to Kwick (1974), behavior is the action of an organism that can be observed and even studied. Based on the study results, physicians' behavior could be observed from their actions when referring cases. Based on the behavior variables, it consisted of four variables. The first was related to when the referral was made. Physicians referred patients when the cases could not be handled at the PHC, there were indications of disease to be referred, and the patients needed further examination. Based on Article 11 of the Minister of Health Regulations No. 1 of 2012 concerning Individual Health Service Referral System, each health care provider is obliged to refer patients if their health problems require it.

The second variable was decision-making in referring patients. Physicians referred NHI patients based on their own decisions. However, in some cases, the patients forced to be referred and even angry and blamed the physician. In such cases, referrals would be given at the patient's request. It was in line with Firdiah et al.'s study which stated that patients who still wished to be referred would be given a referral letter at their request (Firdiah, Sriatmi, \& Fatmasari, 2017). The results were also in line with Utami et al.'s study, which stated that patient demand influenced physicians to refer diseases (Utami, Hendrartini, \& Claramita, 2018). In this study, the physician explained to the patient they did not need to be referred because their disease could be treated at the PHC. Some patients accepted and understood, but others were convinced that specialists would treat them better and still demanded a referral. The last variable was related to the intensity of referrals. The number of referral letters made each day varied depending on the situation, the number of visits, and the departments.

Physicians were susceptible to referring patients because of the patients' condition, the availability of medicines and medical devices, and the patients' affordability to the destination hospital. The physicians referred NHI patients considering the patients' condition and the need for further examination. The hospital was chosen with these considerations and the close distance between the patient's house and the hospital. The study results on the distance variable were in line with Alawi, Junadi, \& Latifah's (2017) study, which found that distance correlated with the high referral rate of National Health Insurance's patients with non-specialist cases by PHCs in Sukabumi. Most physicians were not susceptible to referring patients due to the availability of medicines because the handled cases indeed required particular medicine. Some medical equipment was not yet available at Dempo PHC following MHR No. 75 of 2014 standard, especially in the non-salaried workers' room. However, equipment availability was not significant for non-salaried workers and other department physicians to refer patients; only a few cases were referred because of equipment problems.

Some physicians would feel the consequences if many referred patients got a reduction in services and patients who wanted referrals were reprimanded. However, the triangulation results, obtained from the capitation data receipt and interviews with the primary 
benefit auditor report, and the Palembang Health referral data, showed that the physician felt no impact. The Palembang government's evaluation and admonition regarding referrals and capitation were also not based on additional information from the administration director.

Physicians felt satisfied and more relaxed when the patients were referred because they could help their patients to get better services. The actual referrals were only aimed at patients, including those who could be treated, helped, and handled by appropriate specialists based on their needs. These results were in line with Johnston's study towards Australian general practitioners that referred their patients to pulmonary rehabilitation services based on the perceived benefits that the patients would get (Johnston, Young, Grimmer, Antic, \& Frith, 2013).

Pressure from the patients who forced to be referred was an obstacle in the referral process felt by the Dempo PHC physician. Physicians knew that the diagnosis could be handled and treated at the PHC. Even though it had been explained to the patients, they still forced to be referred. Therefore, the referral was conducted by finding a diagnosis that allowed the patient to be referred to the hospital. Pressure from patients to be referred was also experienced by general practitioners in Norway to younger physicians in Thorsen's (2017) study.

All physicians also experienced technical issues in referring patients, such as power outages and poor internet connection. These obstacles were felt because the referral system required online referrals; referral letters could not be issued when obstacles occurred, whereas the hospital did not accept manual referrals. In line with Indrianingrum's study, an online referral letter was made when a power outage caused the patient to be refused by the hospital and was told to request the original letter (Indrianingrum \& Handayani, 2017). Another issue was that the disease diagnoses were often different from ICD
10 because the patient's symptoms did not match the ICD 10. Different codes caused the diagnoses to be excluded. For such cases, the patient was usually still referred by correcting the diagnosis in the ICD 10.

Obstacles caused by patients were not understanding the referral mechanism, forcing themselves to be referred when their cases were not referable, and incomplete referral requirements also disrupted the implementation of referral. Bustani's study stated that the obstacles that often occurred during the referral process were incomplete files submission by NHI patients when they were called (Bustani, Rattu, \& Saerang, 2015). These results were in line with Eskandari's study regarding the hindrances to the health care referral system in rural communities in Iran. Patients did not understand the referral mechanism, and it was seen from their noncompliance with the referral system hierarchy and referring directly to physicians and more levels explicitly (Eskandari, Abbaszadeh, \& Borhani, 2013).

The physician's decision to refer patients was demonstrated when the physician understood the referral limitation based on the diagnosis of 144 diseases that they should master. A person must feel competent to overcome the perceived obstacles in taking action and have high selfefficacy if they have knowledge and confidence (Wirawan, 2012). These results followed the Minister of Health Regulation No. 5 of 2014 concerning clinical practice guidelines for FLHF physicians that must master the 144 diseases diagnoses as stated in the Indonesia Medical Doctor Competency Standard (SKDI). Confidence in referring patients was also demonstrated when the physician was uncertain about the disease but did not know the diagnosis. The Society of Acute Medicine (SAM) guidelines indicated that all medical patients should be assessed within 4 hours of referral (Holland \& ElKhaleq, 2018). Novitasari's study stated that 
referring patients to colleagues who have higher competence indicates of the physicians' understanding of their competence (Novitasari, Ridlo, \& Kristina, 2017).

Physicians' decisions to refer patients could be categorized into four classifications. In the first classification, if a patient requested referrals based on their own volition with a diagnosis that should not be referred, the physician would provide a referral letter after explaining, examining, and giving medicines to the patient. However, if the patients insisted, they would be told to pay independently as general patients. Ali, in his study, stated that NHI patients at the Siko and Kalumata PHC in Ternate City must follow the existing referral system. Any illness other than an emergency was required to seek treatment in FLHF, it was not permissible to go directly to the hospital, but if patients did not comply, they must pay for the treatment themselves (Ali, 2015).

In other classifications, the physician would refer the patients to their chosen hospital if the hospital is type $\mathrm{C}$, in collaboration with the $\mathrm{PHC}$, and could be a referral facility. Third, the physician would refer patients who are already in the hospital, provided that they had never come to the PHC to ask for a referral letter. However, the PHC physician would request a referral letter from the hospital physician about the patient's diagnosis, or the patient must come to the PHC first. Emergency patients would be allowed to go directly to the hospital and take referrals after that by providing evidence of patient's existence and a cover letter from the hospital. These results followed the referral guidelines based on MHR No. 1 of 2012 stated in Articles 3 to 11 (Ali, 2015). The fourth classification was that the physicians would also refer the patients if they had not recovered for a maximum of three medications. However, the patients would not be referred if the disease was incurable. A physician must respect patients' rights to maintain patient trust and accelerate their recovery, as stated in the Indonesian MCE in 2012.

\section{Conclusion}

Physicians' decision to refer patients was based on existing conditions, procedures, and referral criteria. However, a high referral rate was caused by patients' request to be referred, the patients came with symptoms that they felt could not be handled at the PHC, the patients had gone to the hospital, and there were some cases that should not be referred to but still referred, by entering a diagnosis that was similar to patients' disease in ICD 10. It is suggested that public health centers educate National Health Insurance patients regarding tiered referral procedures in health services facilities.

\section{References}

Alawi, M., Junadi, P., \& Latifah, S. N. (2017). Analisis Faktor-Faktor yang Berhubungan dengan Tingginya Rujukan Kasus Non Spesialistik Pasien Jaminan Kesehatan Nasional pada Puskesmas di Kabupaten Sukabumi Tahun 2015. Jurnal Ekonomi Kesehatan Indonesia, 2(1).

Ali, F. A. (2015). Analisis Pelaksanaan Rujukan Rawat Jalan Tingkat Pertama Peserta Program Jaminan Kesehatan Nasional (JKN) Di Puskesmas Siko Dan Puskesmas Kalumata Kota Ternate Tahun 2014. Jikmu, $5(3)$.

Bustani, N. M., Rattu, A. J., \& Saerang, J. S. (2015). Analisis Lama Waktu Tunggu Pelayanan Pasien Rawat Jalan Di Balai Kesehatan Mata Masyarakat Propinsi Sulawesi Utara. eBiomedik, 3(3).

Coyle, E., Hanley, K., \& Sheerin, J. (2011). Who goes where? A prospective study of referral patterns within a newly established primary 
care team. Irish journal of medical science, 180(4), 845-849.

Eskandari, M., Abbaszadeh, A., \& Borhani, F. (2013). Barriers of referral system to health care provision in rural societies in Iran. Journal of caring sciences, 2(3), 229.

Firdiah, M. R., Sriatmi, A., \& Fatmasari, E. Y. (2017). Analisis Pelaksanaan Rujukan Rawat Jalan Tingkat Pertama Pada Peserta Badan Penyelenggaraan Jaminan Sosial Kesehatan (Studi Kasus di Puskesmas Neglasari Kota Tangerang). Jurnal Kesehatan Masyarakat (e-Journal), 5(3), 19-25.

Førde, O. H., Breidablik, H. J., \& Øgar, P. (2011). Do differences in referral rates threaten the goal of equity in health care? Tidsskrift for den Norske laegeforening: tidsskrift for praktisk medicin, ny raekke, 131(19), 18781881.

Holland, J., \& El-Khaleq, Y. A. (2018). Medical referrals: introducing a GP-priority clerking shift to ensure equitable patient care. Future healthcare journal, 5(1), 37.

Indrianingrum, I., \& Handayani, O. W. K. (2017). Input Sistem Rujukan Badan Penyelanggara Jaminan Sosial (BPJS) Kesehatan di Fasilitas Kesehatan Tingkat Pertama (FKTP) Kabupaten Jepara. Public Health Perspective Journal, 2(2).

Johnston, K. N., Young, M., Grimmer, K. A., Antic, R., \& Frith, P. A. (2013). Barriers to, and facilitators for, referral to pulmonary rehabilitation in COPD patients from the perspective of Australian general practitioners: a qualitative study. Primary Care Respiratory Journal, 22, 319-324.

Kwick, R., 1974. dalam Notoatmodjo, Soekidjo. 2003. Pendidikan Dan Perilaku Kesehatan.
Novitasari, A., Ridlo, S., \& Kristina, T. N. (2017). Instrumen Penilaian Diri Kompetensi Klinis Mahasiswa Kedokteran. Journal of Research and Educational Research Evaluation, 6(1), 81-89.

Ringberg, U., Fleten, N., Deraas, T. S., Hasvold, T., \& Førde, O. (2013). High referral rates to secondary care by general practitioners in Norway are associated with GPs' gender and specialist qualifications in family medicine, a study of 4350 consultations. BMC Health Services Research, 13(1), 1-10.

Thorsen, O. (2017). General practitioners' referrals to specialist health services. Exploring elements and factors in the referral process having an impact om patients' access to specialty care.

Utami, A., Hendrartini, Y., \& Claramita, M. (2018). Persepsi Dokter dalam Merujuk Penyakit nonspesialistik di layanan kesehatan primer dalam jaminan kesehatan nasional (Studi di Daerah Istimewa Yogyakarta). Media Medika Muda, 2(1).

Wirawan, D. I. (2012). Teori-teori Sosial dalam Tiga Paradigma: fakta sosial, definisi sosial, dan perilaku sosial: Kencana. 